\title{
The State of Zirconia Supported Platinum Catalysts for $\mathrm{CO}_{2} / \mathrm{CH}_{4}$ Reforming
}

\author{
J. H. Bitter, K. Seshan, and J. A . Lercher ${ }^{1}$ \\ Faculty of Chemical Technology, Catalytic Processes and M aterials, U niversity of Twente, P.O. B ox 217, 7500 A E , E nschede, The N etherlands
}

Received N ovember 18, 1996; revised June 5, 1997; accepted June 16, 1997

In Pt/Z $\mathrm{ZO}_{2}$ catalysts used for $\mathrm{CO}_{2} / \mathrm{CH}_{4}$ reforming to syngas, not all accessible Pt contributes equally to the activity of the catalyst. The catalytic activity is determined by the accessibility of Pt on the

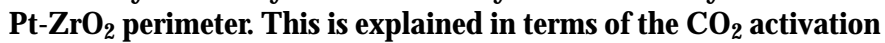
via carbonate species on the support which must be in the proximity of the Pt particles to react with the methane activated on the metal. Thesignificance of the supportis also emphasized by thelow activity of $\mathrm{Pt}$ black and $\mathrm{Pt} / \mathrm{SiO}_{2}$, which were incapable of forming carbonates on the support. The perimeter concentration of $\mathrm{Pt} / \mathrm{ZrO}_{2}$ can be changed by changing the Pt concentration in the catalyst or by increasing the calcination temperature which causes sintering of the Pt particles. In contrast to the calcination temperature, the reduction temperature did not influence the activity although the hydrogen chemisorption capacity was markedly decreased by increasing the reduction temperature. As sintering was excluded on basis of particle size determination from EXAFS results a SMSI state on $\mathrm{Pt} / \mathrm{ZrO}_{2}$ during high temperature reduction is concluded to exist. This state does not persist under reaction conditions due to the presence of adsorbed oxygen from $\mathrm{CO}_{2}$ dissociation.

\section{INTRODUCTION}

Carbon dioxide reforming of methane to produce synthesis gas, i.e., a mixture of carbon monoxide and hydrogen $\left(\mathrm{CO}_{2}+\mathrm{CH}_{4} \quad 2 \mathrm{CO}+2 \mathrm{H}_{2} ; \Delta \mathrm{H}_{298 \mathrm{~K}}^{\circ}=247.0 \mathrm{~kJ} / \mathrm{mol}\right)$ has attracted substantial interest (1-4). The reaction is well suited to produce $\mathrm{CO}$ rich synthesis gas or very pure carbon monoxide for the synthesis of bulk chemicals such as acetic acid, dimethyl ether, and alcohols via the oxoalcohol synthesis (5). More significantly, for acetic acid manufacture carbon dioxide reforming is estimated to have economic advantages over other synthesis gas production routes (6). $\mathrm{H}$ owever, the feasibility of $\mathrm{CO}_{2}$ reforming depends strongly on the price and availability of $\mathrm{CO}_{2}$ and the pressure at which the process will be operated.

The reaction consists of similar elementary reaction steps as steam reforming $\left(\mathrm{H}_{2} \mathrm{O}+\mathrm{CH}_{4} \quad \mathrm{CO}+3 \mathrm{H}_{2} ; \Delta \mathrm{H}_{298 \mathrm{~K}}^{\circ}=\right.$ $206 \mathrm{~kJ} / \mathrm{mol}$ ) (7), but the absence of water and the high $\mathrm{C} / \mathrm{H}$ ratio in the reactant feed favours extensive coke formation (8). Minimization of coking rates is, thus, one of

\footnotetext{
${ }^{1}$ E-mail: J.A .L ercher@utct.ct.utwente.nl.
}

the key aspects for designing a stable catalyst for the reaction. Coke forms readily via methane decomposition $\left(\mathrm{CH}_{4} \rightleftarrows \mathrm{C}+2 \mathrm{H}_{2} ; \Delta \mathrm{H}_{298 \mathrm{~K}}^{\circ}=+74.9 \mathrm{~kJ} / \mathrm{mol}\right)$ and $\mathrm{CO}$ disproportionation ( $2 \mathrm{CO} \rightleftarrows \mathrm{C}+\mathrm{CO}_{2} ; \Delta \mathrm{H}_{298 \mathrm{~K}}^{\circ}=-172.4 \mathrm{~kJ} / \mathrm{mol}$ ). $O$ ptions to reduce the coke build up are (i) the addition of water (coupling with steam reforming), (ii) the addition of oxygen (coupling with partial oxidation), or (iii) the use of catalysts which minimize the rate of coking.

A s early as 1928, Fischer and Tropsch showed that different metals have different activities for $\mathrm{CO}_{2} / \mathrm{CH}_{4}$ reforming and that most group VIII metals show appreciable activity for $\mathrm{CO}_{2} / \mathrm{CH}_{4}$ reforming (9). $\mathrm{M}$ any authors have investigated different metals like $\mathrm{N} \mathrm{i,} \mathrm{R} \mathrm{u,} \mathrm{R} \mathrm{h,} \mathrm{Pt,} \mathrm{I} \mathrm{r,} \mathrm{Pd} \mathrm{(1,} \mathrm{10-13)}$ for the reaction. A lthough there is some debate about the order of activity of these metals, $\mathrm{R} h$ was preferred by most authors due to the good activity and stability for the catalyst. N i catalysts, however, are commercially more interesting compared to noble metals but their main drawback is the high rate of coke formation $(2,12,14,15)$. From an economic point of view (relatively low price and good availability) Pt is a reasonable compromise.

The most commonly used support for $\mathrm{CO}_{2} / \mathrm{CH}_{4}$ reforming is $\mathrm{A}_{2} \mathrm{O}_{3}(2,9,12,16-18)$. M odifications to the support were sometimes made $(9,18,19)$ by addition of basic promoters such as $\mathrm{M} \mathrm{gO}$ and $\mathrm{CaO}$ to enhance catalyst stability. This indicates the importance of the support on the stability of the catalyst. I ndeed a significant influence of the support is observed for Pt catalysts and we have shown earlier that $\mathrm{ZrO}_{2}$ is a very well suited support (20-23).

In order to grasp why $\mathrm{Pt} / \mathrm{ZrO}_{2}$ is a stable and active catalyst it is necessary to understand the nature of $\mathrm{Pt}$ in this catalyst, its interaction with the support and the contribution of $\mathrm{ZrO}_{2}$ to the reaction and the elementary reaction steps that occur. In the present contribution the physical characteristics of the catalyst and their influence on catalytic behaviour is discussed.

\section{METHODS}

Catalyst Preparation

A II catalysts used in this study were prepared by the wet impregnation technique. For this purpose a solution 
of $\mathrm{H}_{2} \mathrm{PtCl}_{6} \cdot 6 \mathrm{H}_{2} \mathrm{O}$ in water $(0.01 \mathrm{~g} \mathrm{Pt}$ per $\mathrm{ml})$ was used. The chosen support was first calcined for $15 \mathrm{~h}$ at $1125 \mathrm{~K}$ (heating rate $3 \mathrm{~K} / \mathrm{min}$ ) in flowing air $(30 \mathrm{ml} / \mathrm{min}(\mathrm{NTP})$ ). The support was then isostatically pressed into pellets at 4000 bars for $5 \mathrm{~min}$. The pellets were crushed and sieved to give grains having diameters between 0.3 and $0.6 \mathrm{~mm}$. The grains were impregnated with the $\mathrm{H}_{2} \mathrm{PtCl}_{6}$ solution to yield a catalyst with $0.5 \mathrm{wt} \% \mathrm{Pt}$. The catalysts were dried at $365 \mathrm{~K}$ for $2 \mathrm{~h}$ in a rotating evaporator followed by drying over night at $395 \mathrm{~K}$ in static air. Subsequently, the impregnated grains were calcined at $925 \mathrm{~K}$ for $15 \mathrm{~h}$ (heating rate $3 \mathrm{~K} / \mathrm{min}$ ). The Pt content of the catalyst was determined by atomic absorption spectroscopy. The following supports were used: $\gamma-\mathrm{A} \mathrm{I}_{2} \mathrm{O}_{3}(000-3 \mathrm{~A} \mathrm{Q}, \mathrm{A} \mathrm{KZO}), \mathrm{TiO}_{2}$ (P-25, Degussa, mixture of anatase and rutile), $\mathrm{SiO}_{2}(\mathrm{AKZO}, \mathrm{F} 7)$, and $\mathrm{ZrO}_{2}$ (R C-100, G imex, monoclinic). The supports had the following surface areas, after calcination at $1125 \mathrm{~K}$ for $15 \mathrm{~h}: \gamma-\mathrm{Al}_{2} \mathrm{O}_{3}, 110 \mathrm{~m}^{2} / \mathrm{g} ; \mathrm{TiO}_{2}, 7 \mathrm{~m}^{2} / \mathrm{g} ; \mathrm{SiO}_{2}, 220 \mathrm{~m}^{2} / \mathrm{g} ; \mathrm{ZrO}_{2}$, $18 \mathrm{~m}^{2} / \mathrm{g}$.

\section{Catalyst Characterizations}

Hydrogen chemisorption measurements. Hydrogen chemisorption was carried out in a volumetric system. The sample (usually $1.5 \mathrm{~g}$ ) was reduced for $2 \mathrm{~h}$ at $673 \mathrm{~K}$ in $\mathrm{H}_{2}$ (when a higher reduction temperature was required, the sample was previously reduced ex situ at the higher temperature). A fter reduction the sample was degassed at $673 \mathrm{~K}$ for $1 \mathrm{~h}$ in high vacuum $\left(10^{-6} \mathrm{mbar}\right)$. The sample was cooled to room temperature $(295 \mathrm{~K})$ and the $\mathrm{H}_{2}$ adsorption isotherm was measured by feeding decreasing amounts of $\mathrm{H}_{2}$ (in the range 500-0 mbar) to the sample. The hydrogen chemisorption capacity was calculated by extrapolation of the hydrogen uptake to zero pressure.

The length of the $\mathrm{Pt}-\mathrm{Z} \mathrm{rO}_{2}$ perimeter was calculated from hydrogen chemisorption values ( $\mathrm{H} / \mathrm{Pt})$. From the $\mathrm{H} / \mathrm{Pt}$ ratios particle sizes could be calculated using data published by K ip et al. (24) and Vaarkamp et al. (25). The same models were used to calculate metal dispersion based on the hydrogen chemisorption capacity. The H/Pt stoichiometry increases with decreasing particle size because smaller particles have a higher concentration of edges and corners, where more than one hydrogen atom per metal atom can adsorb, than larger particles $(24,25)$. Thus, by using these models varying $\mathrm{H} / \mathrm{Pt}$ ratios were used for calculation the $\mathrm{Pt}$ dispersion.

XAS measurements. XAS measurements were performed at the Synchrotron facility in Daresbury (beamline 9.2). The catalyst powder was pressed into a selfsupporting wafer ( $110 \mathrm{mg}$ for $\mathrm{Pt} / \mathrm{ZrO}_{2}$ and $300 \mathrm{mg}$ for $\mathrm{Pt} /$ $\gamma-\mathrm{Al}_{2} \mathrm{O}_{3}$, both catalysts contained 1 wt\% Pt). The catalysts were ex situ reduced at the desired temperature. Prior to the EXAFS experiments catalysts were rereduced in situ at $675 \mathrm{~K}$. EXAFS measurements were carried out at liq- uid nitrogen temperature. To isolate the EXA FS from the $X$-ray absorption edge, a polynomial function characteristic of the background was subtracted. The oscillations were normalized by the mass areal loading of the metal. The oscillations were $\mathrm{k}^{2}$-weighted and Fourier transformed within the limits $k=3.5$ to $k=18$ to isolate the contributions of the different coordination shells.

IR spectroscopic measurement of $\mathrm{CO}_{2}$ adsorption on $\mathrm{Pt} / \mathrm{ZrO}_{2}$. The catalyst powder was pressed into a selfsupporting wafer. This wafer was analyzed in situ during the reaction by means of transmission absorption IR spectroscopy using a Bruker IFS 88 FTIR spectrometer (resolution $4 \mathrm{~cm}^{-1}$ ). The IR cell was constructed as a continuously stirred tank reactor (volume $1.5 \mathrm{~cm}^{3}$ ) equipped with $\frac{1}{16}$-in. gas in- and outlet tubing and $\mathrm{CaF}_{2}$ windows. The partial pressure of each of the reactants $\left(\mathrm{CO}_{2}\right.$ and $\left.\mathrm{CH}_{4}\right)$ was 250 mbar, the difference to 1 bar being $\mathrm{He}$.

Catalyst testing. Typically $300 \mathrm{mg}$ of catalyst were loaded into a tubular quartz reactor (inner diameter $5 \mathrm{~mm}$ ) which was placed in an oven. The catalyst grains were kept in place by quartz wool plugs. A thermocouple was placed on top of the catalyst bed to measure the catalyst temperature. The oven temperature was controlled by a $\mathrm{E}$ urotherm temperature controller. The catalysts were reduced in situ with $5 \% \mathrm{H}_{2}$ in $\mathrm{N}_{2}$ for $1 \mathrm{~h}$ at $1125 \mathrm{~K}$. A fter reduction the temperature was lowered in $\mathrm{A} r$ to the (initial) reaction temperature and the feed gas mixture $\left(25 \% \mathrm{CH}_{4}\right.$ (vol), $25 \% \mathrm{CO}_{2}$, $5 \% \mathrm{~N}_{2}$, and $45 \% \mathrm{Ar}$ for a total flow of $170 \mathrm{ml} \cdot \mathrm{min}^{-1}$ ) was switched to the reactor. The reaction products were analysed in a gas chromatograph (Varian 3300), equipped with two 3-m carbosieve columns and a TCD.

\section{RESULTS}

Influence of the F raction of A ccessible Pt

Previous work from our group showed that $1 \mathrm{wt} \% \mathrm{Pt} /$ $\mathrm{ZrO}_{2}$ was an excellent catalyst for $\mathrm{CO}_{2} / \mathrm{CH}_{4}$ reforming in (20-23). It operated for $500 \mathrm{~h}$ without significant deactivation. In Fig. 1 the activity of 0.5 and 1 wt $\mathrm{Pt} / \mathrm{ZrO}_{2}$ at $875 \mathrm{~K}$ are shown. The physico-chemical characteristics of these catalysts are compiled in Table 1 . N ote that both catalysts showed allmost the same activity although the $1 \mathrm{wt} \%$ catalyst exposed more Pt atoms compared to the $0.5 \mathrm{wt} \%$ catalyst (Table 1).

Figure 2 displays the variation of the catalytic activity at $875 \mathrm{~K}$ and the accessible Pt concentration for the series of $\mathrm{Pt} / \mathrm{Z} \mathrm{rO}_{2}$ catalysts with different Pt loadings. With increasing metal loading the concentration of accessible Pt increased. However, while at a low Pt content $(<0.5$ wt $\%)$ the activity increased with increasing metal loading, the increase in activity stagnated at higher metal loading $(>0.5 \mathrm{wt} \%)$. This could not be due to blocking of the pores by Pt because adsorption/desorption studies showed that the average pore 


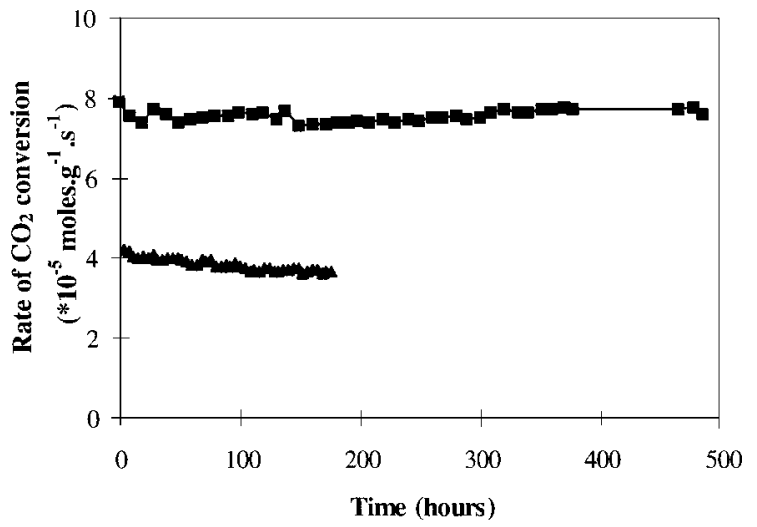

FIG . 1. A ctivity of 0.5 and $1 \mathrm{wt} \% \mathrm{Pt} / \mathrm{ZrO} \mathrm{ratalysts}_{2}$ for $\mathrm{CO}_{2} / \mathrm{CH}_{4}$ reforming at $900 \mathrm{~K}, \mathrm{CO}_{2} / \mathrm{CH}_{4} / \mathrm{He} / \mathrm{N}_{2}=42 / 42 / 75 / 10,300 \mathrm{mg}$ catalyst, $\mathbf{\square}=$ $1 \mathrm{wt} \% \mathrm{Pt} / \mathrm{ZrO}_{2}\left({ }^{*} 2\right), \boldsymbol{\Delta}=0.5 \mathrm{wt} \% \mathrm{Pt} / \mathrm{ZrO}_{2}$.

size is $28 \mathrm{~nm}$ and cylindrical in shape, whereas the largest Pt particle size is $2 \mathrm{~nm}$ (Table 1 ). U sing catalysts with different grain sizes $(0.1-1.0 \mathrm{~mm}$ in fractions of $0.1 \mathrm{~mm})$ revealed that the $\mathrm{CO}_{2}$ conversion was independent of the grain size, thus, internal mass transfer limitations were ruled out. A Iso external mass transfer limitations could be ruled out since the use of varying amounts of catalyst (200-600 mg catalyst) and keeping the contact time constant, i.e., at constant $\mathrm{W} / \mathrm{F}$ ( $\mathrm{W}=$ catalyst mass, $\mathrm{F}=$ total gas flow) did not show an influence on the conversion. In the above experiment, changing the gas flow, at constant contact time, changes the amount of heat that could be transferred from the gas phase. Since this and the fact that changing the diluent $(\mathrm{He}$ or A r) did not influence the activity it is concluded that heat transfer limitations were absent. Thermodynamic limitations were also ruled out since the carbon dioxide conversion calculated from thermodynamics is $55 \%$ at $875 \mathrm{~K}$, whereas the maximum conversion observed under the experimental conditions is $33 \%$ (Fig. 2). It is therefore con-

\section{TABLE 1}

\section{Physico-C hemical C haracteristics of $\mathrm{Pt} / \mathrm{ZrO}_{2} \mathrm{C}$ atalysts with Different Metal Loadings}

\begin{tabular}{ccccc}
\hline $\begin{array}{c}\text { Hydrogen } \\
\text { Pt loading } \\
\text { (wt\%) }\end{array}$ & $\begin{array}{c}\text { chemisorption } \\
\text { capacity } \\
\text { (H /M })\end{array}$ & $\begin{array}{c}\text { Pt dispersion } \\
(\%)\end{array}$ & $\begin{array}{c}\text { Pt particle }_{\text {size }^{\mathrm{a}}} \\
(\mathrm{nm})\end{array}$ & $\begin{array}{c}\text { BET } \\
\text { surface area } \\
\left(\mathrm{m}^{2} / \mathrm{g}\right)\end{array}$ \\
\hline 0.2 & $1.35 \pm 0.1$ & 100 & 0.8 & 18 \\
0.3 & $1.30 \pm 0.1$ & 100 & 0.8 & 20 \\
0.4 & $1.25 \pm 0.1$ & 100 & 0.9 & 19 \\
0.5 & $1.10 \pm 0.1$ & 100 & 1.0 & 18 \\
0.7 & $1.01 \pm 0.1$ & 97 & 1.2 & 18 \\
1.0 & $0.82 \pm 0.1$ & 80 & 1.3 & 17 \\
2.0 & $0.61 \pm 0.1$ & 58 & 1.9 & 20
\end{tabular}
(24).

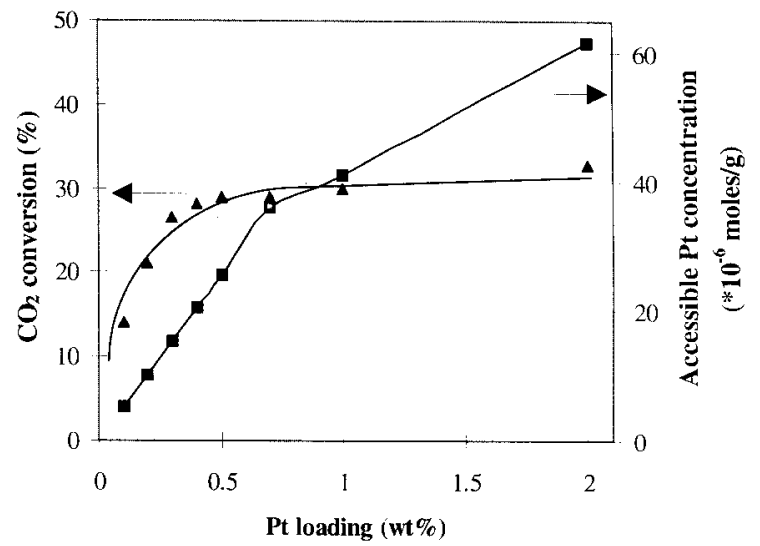

FIG. 2. Influence of the Pt-loading on the amount of accessible Pt and the activity of $\mathrm{Pt} / \mathrm{ZrO}_{2}$ catalysts for $\mathrm{CO}_{2} / \mathrm{CH}_{4}$ reforming at $875 \mathrm{~K}$, $\mathrm{CO}_{2} / \mathrm{CH}_{4} / \mathrm{H} \mathrm{e} / \mathrm{N}_{2}=42 / 42 / 75 / 10,300 \mathrm{mg}$ catalyst.

cluded that the nonlinear dependence for the activity of $\mathrm{Pt} / \mathrm{ZrO}_{2}$ as a function of the accessible Pt area is a result of a change in the catalytic properties at higher metal concentrations.

The activity of Pt catalysts for $\mathrm{CO}_{2} / \mathrm{CH}_{4}$ reforming per accessible Pt atom is a compiled in Table 2. The unsupported Pt black catalyst was prepared as described by Paal et al. (26) using the "hydrazine method." A fter reduction of the catalyst at $975 \mathrm{~K}$ its surface area was $0.25 \mathrm{~m}^{2} / \mathrm{g}$ (measured by the BET method and calculated from hydrogen chemisorption). From Table 2 it can be seen that the catalytic activity of Pt-black (TOF) is two orders of magnitude lower compared to $\mathrm{Pt} / \mathrm{ZrO}_{2}, \mathrm{Pt} / \mathrm{TiO}{ }_{2}$, and $\mathrm{Pt} / \gamma-\mathrm{Al}_{2} \mathrm{O}_{3}$. The activity of Pt-black compares, however, well with the low activity of $\mathrm{Pt} / \mathrm{SiO}_{2}$. This leads to the conclusion that the use of a suitable support can strongly increase the activity of the Pt metal. The positive involvement of the support for the reaction was shown by the use of $\mathrm{Pt}$-black impregnated with a solution of $\mathrm{ZrOCl}_{2}$ (and subsequent calcination and reduction at $875 \mathrm{~K}$ ). The activity per accessible Pt atom of this catalyst was increased by an order of magnitude compared to the untreated Pt-black sample. The increase in activity of Pt-black after impregnation with $\mathrm{ZrO} \mathrm{Cl}_{2}$ indicates

\section{TABLE 2}

Comparison of the Activities of D ifferent Pt-C atalysts ( $0.5 \mathrm{wt} \% \mathrm{Pt}$ / Support), $T=925 \mathrm{~K}, \mathrm{C} \mathrm{O}_{2} / \mathrm{CH}_{4} / \mathrm{He}+\mathrm{N}_{2}=50 / 50 / 50100 \mathrm{ml} \cdot \mathrm{min}^{-1}$

\begin{tabular}{lcc}
\hline \multicolumn{1}{c}{ Catalyst } & $\begin{array}{c}\text { Pt surface area } \\
\left(\mathrm{m}^{2} / \mathrm{g}\right)\end{array}$ & $\begin{array}{c}\text { TOF of } \mathrm{CO}_{2} \\
\left(\mathrm{~s}^{-1}\right)\end{array}$ \\
\hline $\mathrm{Pt} / \mathrm{ZrO}{ }_{2}$ & 1.2 & 20 \\
$\mathrm{Pt} / \gamma-\mathrm{Al}_{2} \mathrm{O}_{3}$ & 0.96 & 25 \\
$\mathrm{Pt} / \mathrm{TiO}_{2}$ & 0.31 & 52 \\
$\mathrm{Pt} / \mathrm{SiO}_{2}$ & 0.15 & 0.2 \\
$\mathrm{Pt}-$ black & 0.25 & 0.1 \\
$\mathrm{Pt}-$ black $/ \mathrm{ZrO}$ & & 1.1 \\
\hline
\end{tabular}




\section{TABLE 3}

Influence of the $\mathrm{C}$ alcination Temperature on Activity, $\mathrm{H}$ ydrogen Chemisorption Capacity, and $\mathrm{Pt}$ Coordination $\mathrm{N}$ umber of $\mathrm{Pt} / \mathrm{ZrO}_{2}$

\begin{tabular}{ccccc}
\hline $\begin{array}{c}\text { Metal } \\
\text { loading } \\
\text { (wt\%) }\end{array}$ & $\begin{array}{c}\text { Calcination } \\
\text { temperature } \\
\text { (K) }\end{array}$ & $\begin{array}{c}\text { Coordination } \\
\text { number from } \\
\text { EXA FS }^{b}\end{array}$ & $\begin{array}{c}\text { Hydrogen } \\
\text { chemisorption } \\
\text { capacity }(\mathrm{H} / \mathrm{Pt})\end{array}$ & $\begin{array}{c}\mathrm{CO}_{2} \\
\text { conversion at } \\
875 \mathrm{~K}(\%)\end{array}$ \\
\hline 1 & 925 & $6.5(86)$ & $0.82(80)$ & 30 \\
1 & 1125 & $10.7(20)$ & $0.33(33)$ & 8 \\
0.5 & 925 & - & $1.1(100)$ & 29 \\
0.5 & 1025 & - & $0.50(48)$ & 24 \\
0.5 & 1125 & - & $0.35(33)$ & 7 \\
\hline
\end{tabular}

${ }^{a}$ To avoid a SM SI state (see D iscussion) the catalysts were reduced at $775 \mathrm{~K}$

${ }^{\mathrm{b}} \mathrm{N}$ umber between brackets denotes the Pt dispersion (\%) as calculated from the coordination number (24).

${ }^{\mathrm{C}} \mathrm{N}$ umber between brackets denotes the $\mathrm{Pt}$ dispersion (\%) as calculated from the $\mathrm{H} / \mathrm{Pt}$ ratio (24).

clearly that $\mathrm{ZrO}_{2}$ contributes to the activity of $\mathrm{Pt} / \mathrm{ZrO}_{2}$ for the reforming reaction.

\section{Influence of $\mathrm{P}$ retreatment $\mathrm{P}$ rocedure}

A lthough $\mathrm{Pt} / \mathrm{ZrO}_{2}$ is a stable and active catalyst for $\mathrm{CO}_{2} / \mathrm{CH}_{4}$ reforming, the catalyst is sensitive to the preparation procedure, in particular the calcination temperature. The preparation of the catalyst involved calcination of the support grains, followed by impregnation of the grains with a $\mathrm{H}_{2} \mathrm{PtCl}_{6}$ solution. This catalyst precursor was calcined prior to in situ reduction and testing. The temperature of calcination of the blank support did not influence the activity of the catalyst, although the surface area (BET) decreased from 33 to $18 \mathrm{~m}^{2} / \mathrm{g}$ when the calcination temperature was increased from 925 to $1125 \mathrm{~K}$. O n the other hand, the calcination temperature after impregnation had a significant influence on the activity of the catalyst due to Pt metal area loss. This can be seen from the EXAFS data from this sample, which showed an increase in coordina-

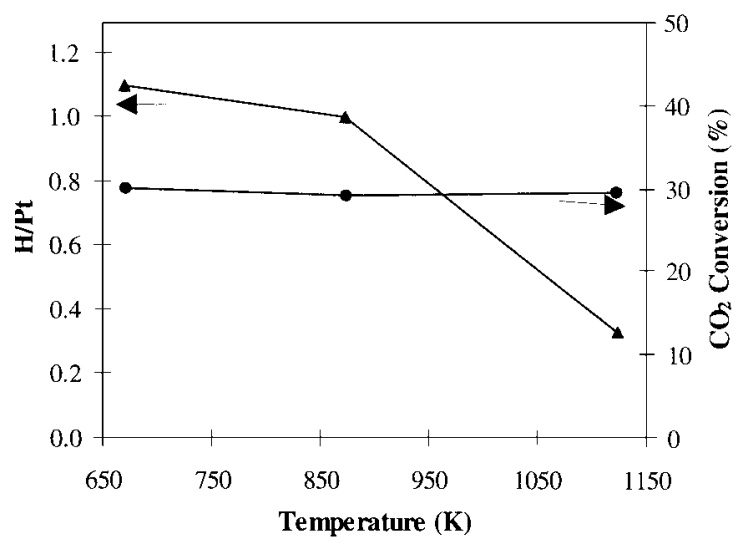

FIG. 3. Influence of the reduction temperature of $\mathrm{Pt} / \mathrm{ZrO}_{2}$ on the hydrogen chemisorption capacity and activity of the catalyst.

tion number from 6.5 to 10.7 when the calcination temperature was increased from 925 to $1125 \mathrm{~K}$ (Table 3). These results were confirmed by hydrogen chemisorption measurements which showed a decrease of $\mathrm{H} / \mathrm{Pt}$ ratio from 0.82 to 0.33 asthe calcination temperature was increased. Consequently, increasing the calcination temperature of the catalyst caused therefore a significant drop in activity (Table 3).

The temperature of in situ reduction, prior to testing of the catalyst, did not influence the activity of the $\mathrm{Pt} / \mathrm{Z} \mathrm{rO}_{2}$ catalyst (Fig. 3). H owever, with increasing reduction temperature (from 675 to $1125 \mathrm{~K}$ ) the hydrogen chemisorption capacity of the catalysts decreased significantly (the H/Pt ratio decreased from 1.1 to 0.33 ; Fig. 3), indicating sintering. E X A FS measurements, on the other hand, showed that the Pt coordination number and, thus, the Pt particle size did not increase (Table 4). The values for the percentage of metal exposed obtained by hydrogen chemisorption for samples that were reduced at low temperature ( $775 \mathrm{~K})$ and by EXAFS are in good agreement. When a $\mathrm{Pt} / \mathrm{ZrO}_{2}$ catalyst with an apparent low dispersion $(\mathrm{H} / \mathrm{Pt}=0.33$, reduction temperature $1125 \mathrm{~K}$ ) was treated with $0.1 \% \mathrm{O}_{2}$ or air a higher dispersion ( $\mathrm{H} / \mathrm{Pt}=0.7$ ) was obtained (Table 4). This

\section{TABLE 4}

\section{Influence of the Reduction Temperature on Activity, Hydrogen C hemisorption C apacity, and Pt Coordination $\mathrm{N}$ umber of $\mathrm{Pt} / \mathrm{ZrO}_{2}$}

\begin{tabular}{|c|c|c|c|c|c|}
\hline Catalyst & $\begin{array}{l}\text { Reduction temperature } \\
\text { (K) }\end{array}$ & $\begin{array}{l}\text { Coordination number } \\
\text { from EXAFS }\end{array}$ & $\begin{array}{c}\text { Dispersion from EXA FS } \\
(\%)\end{array}$ & $\mathrm{H} / \mathrm{Pt}^{\mathrm{b}}$ & $\begin{array}{c}\mathrm{CO}_{2} \text { conversion } \\
\text { at } 875 \mathrm{~K}(\%)\end{array}$ \\
\hline $1 \mathrm{wt} \% \mathrm{Pt} / \mathrm{ZrO}_{2}$ & 775 & 6.5 & 86 & $0.82(80)$ & 30 \\
\hline $1 \mathrm{wt} \% \mathrm{Pt} / \mathrm{ZrO}_{2}$ & 1125 & 7.0 & 81 & $0.33(33)$ & 29 \\
\hline $0.5 \mathrm{wt} \% \mathrm{Pt} / \mathrm{ZrO}_{2}$ & 775 & - & - & $1.1(100)$ & 29 \\
\hline $0.5 \mathrm{wt} \% \mathrm{Pt} / \mathrm{ZrO}_{2}$ & 1125 & - & - & $0.35(33)$ & 28 \\
\hline $0.5 \mathrm{wt} \% \mathrm{Pt} / \mathrm{ZrO}_{2}$ & $1125 / 875 / 675^{a}$ & - & - & $0.70(67)$ & 28 \\
\hline
\end{tabular}

${ }^{a}$ First temperature $(1125 \mathrm{~K})$ is the initial reduction temperature; second temperature is the oxidation temperature; third temperature is the reduction temperature before chemisorption measurement.

${ }^{\mathrm{b}} \mathrm{N}$ umber between brackets denotes the Pt dispersion (\%) as calculated from the H/Pt ratio (24). 


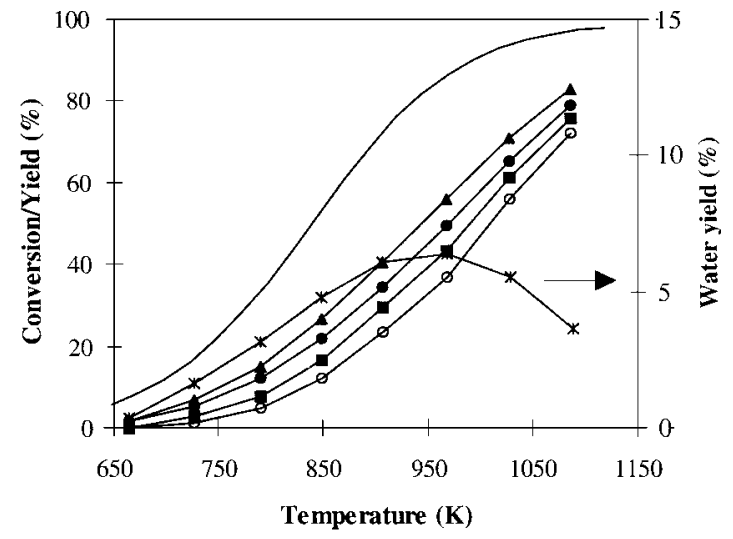

FIG . 4. A ctivity of 0.5 wt $\% \mathrm{Pt} / \mathrm{ZrO}_{2}, 300 \mathrm{mg}$ catalyst, total flow $=$ $170 \mathrm{ml} \cdot \mathrm{min}^{-1}, \mathrm{CO}_{2} / \mathrm{CH}_{4} / \mathrm{N}_{2}+\mathrm{He}=1 / 1 / 2\left(\boldsymbol{\Delta}=\mathrm{CO}_{2}, \boldsymbol{O}=\mathrm{CO}, \boldsymbol{\square}=\mathrm{CH}_{4}\right.$, $\mathrm{O}=\mathrm{H}_{2}, *=\mathrm{H}_{2} \mathrm{O},-=\mathrm{CO}_{2}$ thermodynamic conversion).

indicates that part of the metal area is lost due to covering with (presumably partially reduced) $\mathrm{ZrO}_{2}$ (a SMSI type state) $(28,29)$.

The activity of 0.5 wt $\% \mathrm{Pt} / \mathrm{ZrO}_{2}$ as function of temperature is plotted in Fig. 4. For comparison, the conversions and yields as predicted by thermodynamics are shown in Fig. 5. U nder the chosen reaction conditions $\mathrm{Pt} / \mathrm{ZrO}_{2}$ did not reach thermodynamic conversions. It can be seen from Fig. 5 that, in addition to $\mathrm{H}_{2}$ and $\mathrm{CO}$, a significant amount of water was also produced. The water yield showed a maximum at $950 \mathrm{~K}$. The $\mathrm{H}_{2} / \mathrm{CO}$ ratio was al ways smaller than 1 and tended to 1 only at higher temperatures. The methane conversion was always lower than the $\mathrm{CO}_{2}$ conversion, although they were present in the feed in a 1:1 ratio.

\section{DISCUSSION}

Figure 1 demonstrates clearly that both 0.5 and 1 wt\% $\mathrm{Pt} / \mathrm{Z} \mathrm{O}_{2}$ are stable catalysts for $\mathrm{CO}_{2} / \mathrm{CH}_{4}$ reforming. It is,

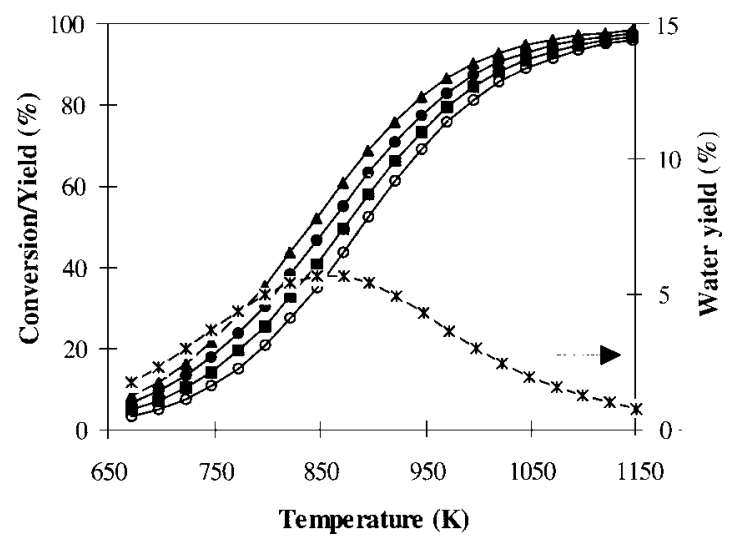

FIG. 5. E quilibrium conversions and yield as predicted by thermodynamics for $\mathrm{C} \mathrm{CO}_{2} / \mathrm{CH}_{4} / \mathrm{He}=1 / 1 / 2$ mixture $\left(\boldsymbol{\Delta}=\mathrm{CO}_{2}, \boldsymbol{O}=\mathrm{CO}, \mathbf{\square}=\mathrm{CH}_{4}\right.$, $\left.\mathrm{O}=\mathrm{H}_{2}, *=\mathrm{H}_{2} \mathrm{O}\right)$. however, remarkable that both catalysts showed similar activities for the reforming reaction, while the former catalyst has a lower amount of exposed Pt compared to the latter (Table 1). A s can be seen in Fig. 2 there is no simple relation between accessible Pt area and the activity of the catalyst. For catalysts with Pt contents above 0.5 wt\% the amount of accessible Pt still increases, whereas the activity of the catalyst remains almost constant. Pore blocking, heat and mass transfer, as well as thermodynamic limitations, were ruled out by appropriate experiments (see results). It is thus concluded that not all accessible Pt contributes equally to the activity of the catalyst. When the activity of the catalyst was plotted as function of the Pt concentration on the $\mathrm{Pt}-\mathrm{ZrO}_{2}$ perimeter a linear dependence is observed (Fig. 6). The lengths of the different perimeters obtained for $\mathrm{Pt} /{\mathrm{Z} \mathrm{rO}_{2}}_{2}$ catalysts with different metal loadings are represented by the diamonds $(\bullet)$. A Iternatively, the perimeter length was varied by changing the calcination temperature of the $0.5 \mathrm{wt} \% \mathrm{Pt} / \mathrm{ZrO}_{2}$ catalyst. I ncreasing the calcination temperature $(925,1025,1125 \mathrm{~K})$ decreased the dispersion of this catalyst due to sintering (Table 3 ) which resulted in a decrease of the concentration of the $\mathrm{Pt}-\mathrm{ZrO}_{2}$ perimeter. These three points (calcination temperature $=925,1025$, and $1125 \mathrm{~K}$ ) are also shown in Fig. 6 and represented by the asterisks $(*)$. These points also fit very well the line in the figure which describes the linear relation between the Pt perimeter and activity for the catalyst. This also indicates that the higher calcination temperature changed the perimeter concentration, but does not change the nature of the active sites.

The linear relation between the amount of Pt on the perimeter and the activity can either imply that the reaction takes place on the $\mathrm{Pt}-\mathrm{ZrO}_{2}$ perimeter or that the migration of a species formed on the support to the metal is rate determining in the reaction. When $\mathrm{ZrO}_{2}$ was impregnated on Pt-black the activity of Pt-black was increased by an order

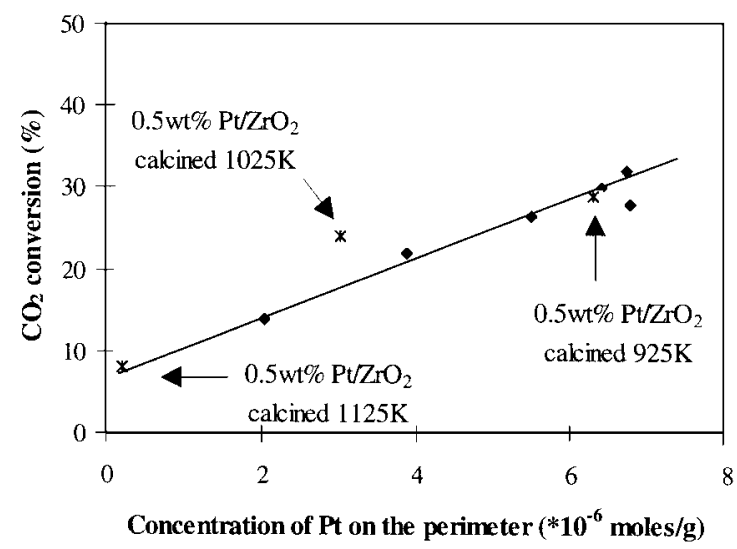

FIG. 6. Influence of the amount of accessible Pt on the activity of $\mathrm{Pt} / \mathrm{ZrO}_{2}$ catalysts for $\mathrm{CO}_{2} / \mathrm{CH}_{4}$ reforming at $875 \mathrm{~K}$. $\diamond=\mathrm{Pt} / \mathrm{ZrO}_{2}, *=$ $0.5 \mathrm{Pt} / \mathrm{ZrO}_{2}$ calcined at different temperatures. 
of magnitude. This clearly shows that although $\mathrm{Pt}$ alone is active for $\mathrm{CO}_{2} / \mathrm{CH}_{4}$ reforming the activity can be significantly enhanced by the presence of a support. The enhancement of catalyst activity by the support was also shown for different other reactions. L evin et al. $(30,31)$ observed for $\mathrm{CO}_{2} / \mathrm{CO}$ methanation an increase in the activity of $\mathrm{R} h$ when it was decorated by partially reduced titania. Similar observations were made by $B$ offa et al. using oxides like $\mathrm{NbO}_{x}, \mathrm{TaO}_{x}$, and $\mathrm{ZrO}_{x}$ (32). Koerts et al. $\mathrm{Ob}$ served a decrease of the activation energy for CO methanation over $\mathrm{Rh} / \mathrm{SiO}_{2}$ when the catalyst was doped with vanadium indicating the significance of the support for this reaction (33). The involvement of the support in the reaction mechanism was also shown for the watergas-shift reaction $\left(\mathrm{CO}+\mathrm{H}_{2} \mathrm{O} \quad \mathrm{H}_{2}+\mathrm{CO}_{2}\right)$. A mechanism involving the formation of formates on the support, their migration to the metal, followed by decomposition on the metal was discussed (34). The importance of the support for the reforming reaction is also substantiated by the use of Pt-black which is at least two orders of magnitude less active, compared to $\mathrm{Pt} / \mathrm{ZrO}_{2}$ (Table 2).

$\mathrm{H}$ aving established that the perimeter is decisive for dry methane reforming, the remaining question to be addressed isthe role of the support on a molecular level. I nfrared spectroscopic studies of $\mathrm{CO}_{2}$ adsorption on Pt-catalysts showed the formation of linearly bound $\mathrm{CO}$ on $\mathrm{Pt}$, and carbonate type species on the support for $\mathrm{Pt} / \gamma-\mathrm{Al}_{2} \mathrm{O}_{3}, \mathrm{Pt} / \mathrm{TiO} \mathrm{O}_{2}$, and $\mathrm{Pt} / \mathrm{ZrO}_{2}$ (Fig. 7), although the type of carbonate species seems to be different for the various supports. $\mathrm{Pt} / \mathrm{SiO}_{2}$ did not show the formation of carbonate type species on the support while it proved to be active for methane decomposition. O n Pt-black no carbonates could be formed on the support because this catalyst is unsupported. In general, it can be concluded that the catalysts which could form carbonates on the support ( $\mathrm{Pt} / \gamma-\mathrm{A} \mathrm{I}_{2} \mathrm{O}_{3}, \mathrm{Pt} / \mathrm{TiO} \mathrm{O}_{2} \mathrm{Pt} / \mathrm{Z} \mathrm{rO}$, and $\mathrm{Pt}-$ black $/ \mathrm{ZrO}_{2}$; see Table 2 ) showed a much higher activity compared to the catalysts which could not form carbonates on the support (Pt-black, $\mathrm{Pt} / \mathrm{SiO}_{2}$ ). N ote in this context

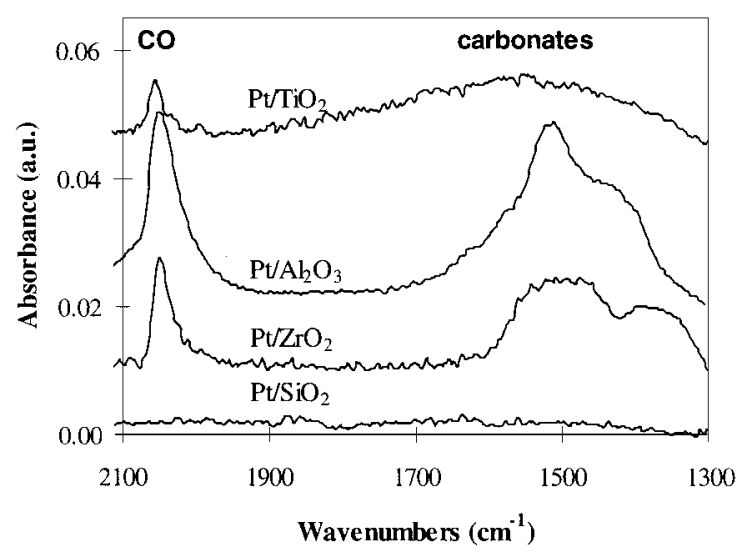

FIG. 7. Infrared spectra of $\mathrm{CO}_{2}$ adsorption on different Pt catalysts, $\mathrm{T}=775 \mathrm{~K}, \mathrm{pCO}_{2}=0.25$, total flow $=30 \mathrm{ml} \cdot \mathrm{min}^{-1}$.

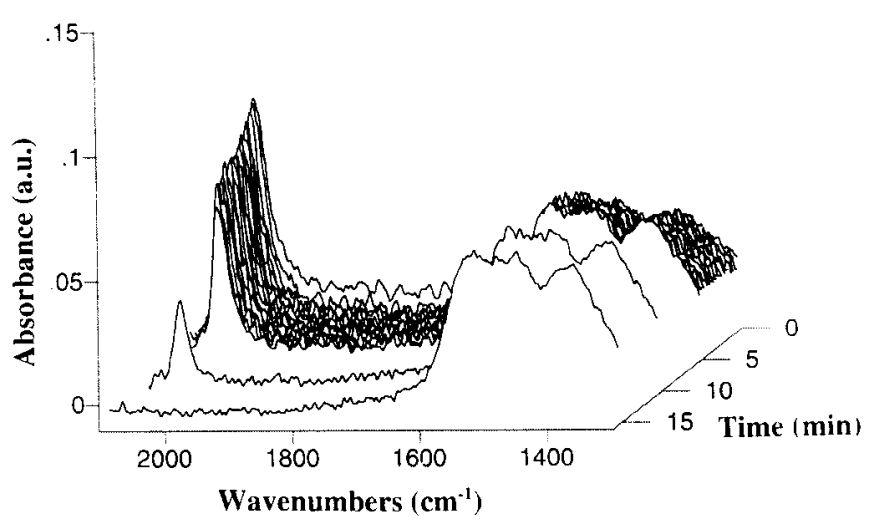

FIG . 8. Time resolved IR spectra during $\mathrm{CO}_{2}$ adsorption on $\mathrm{Pt} / \mathrm{Z} \mathrm{rO}_{2}$, $\mathrm{T}=775 \mathrm{~K}, \mathrm{pCO}_{2}=0.25$, total flow $30 \mathrm{ml} \cdot \mathrm{min}^{-1}$.

that the importance of carbonate, for $\mathrm{CO}_{2} / \mathrm{CH}_{4}$ reforming, was previously suggested by $\mathrm{N}$ akamura et al. (13). They reported that the activity of a $\mathrm{R} \mathrm{h} / \mathrm{SiO}_{2}$ catalyst which did not form carbonates was enhanced by adding $\mathrm{M} \mathrm{gO}, \mathrm{Al}_{2} \mathrm{O}_{3}$, or $\mathrm{TiO}_{2}$, i.e., compounds which facilitate carbonate formation. Figure 8 shows that during prolonged exposure of $\mathrm{Pt} / \mathrm{ZrO}_{2}$ to $\mathrm{CO}_{2}$ the band characteristic for adsorbed $\mathrm{CO}$ disappeared. This is explained in the following way; the carbonate formed on the support boundary decomposed on the metal to $\mathrm{CO}$ and adsorbed oxygen. The $\mathrm{CO}$ desorbs, whereas the adsorbed oxygen covers the Pt boundary making it inactive for further carbonate decomposition. When the oxygen atom is scavenged by methane the sites become available again for reaction. $B$ ased on the above results we propose a bifunctional mechanism for reforming. $\mathrm{CO}_{2}$ is activated on the support, whereas methane is activated on the metal. The two activated species may react with each other on the $\mathrm{Pt}-\mathrm{ZrO}_{2}$ boundary.

A lthough $\mathrm{Pt} / \mathrm{Z} \mathrm{rO}_{2}$ is an active catalyst for $\mathrm{CO}_{2} / \mathrm{CH}_{4}$ reforming care has to be taken during the preparation of the catalyst to ensure a large $\mathrm{Pt}-\mathrm{ZrO}_{2}$ boundary. When the catalyst precursor (after impregnation of the support) is calcined at $1125 \mathrm{~K}$ the activity of the catalyst decreased compared to a catalyst calcined at $925 \mathrm{~K}$ (Table 3). The increase in calcination temperature decreased the hydrogen chemisorption capacity of the catalyst. The Pt-Pt coordination number as calculated from EX A F S also increased with increasing the calcination temperature. This shows clearly that the decrease in activity was caused by sintering of the Pt particles. On the other hand, the reduction temperature does not affect the activity of $\mathrm{Pt} / \mathrm{ZrO}_{2}$. However, the hydrogen chemisorption capacity of this catalyst markedly decreased with increasing reduction temperature (Fig. 3, Table 4). The decrease in hydrogen chemisorption capacity is not affiliated with a decrease in activity. X A FS measurements showed that the Pt particle size is not affected by the reduction temperature (Table 4). It is clear from these results that sintering does not occur during reduction. Thus we conclude that $\mathrm{Pt} / \mathrm{ZrO}_{2}$ catalysts have a "strong metal 
support interaction" (SM SI) which has been identified for $\mathrm{Pt} / \mathrm{TiO}_{2}$ catalysts $(28,29)$ and is also reported to occur on $\mathrm{ZrO}_{2}$ containing catalysts $(35,36)$. In the SM SI state Pt is decorated by the partially reduced oxide suppressing the hydrogen chemisorption capacity, but leaving the particle size unaffected. This process can be reversed by $\mathrm{O}_{2}$ or water. 0 ur results showed that the SM SI state could be reverted by oxygen treatment of the sample (Table 4). D uring reaction conditions this SM SI state is absent, since it is possible to dissociate $\mathrm{CO}_{2}$ on the catalyst to $\mathrm{CO}$ and $\mathrm{O}_{\text {ads }}$ as shown by IR spectroscopy (Figs. 7+8). The $\mathrm{O}_{\text {ads }}$ might be responsible for oxidizing the $\mathrm{ZrO}_{x}$ species on the Pt and, thus, minimizing the extent of decoration with oxide islands. Because the SM SI state is not present under reaction conditions, the fraction of metal exposed after low temperature reduction is representative for the Pt availability under reaction conditions.

Figure 4 shows that the $\mathrm{H}_{2} / \mathrm{CO}$ ratio in the product stream is not one as expected from the stoichiometric reforming reaction. This is not surprising, considering that thermodynamics (Fig. 5) predicts a $\mathrm{H}_{2} / \mathrm{CO}$ ratio of unity only at temperatures above $1150 \mathrm{~K}$. This is affiliated with the reverse watergas-shift reaction (RWGS). The reaction consumes part of the $\mathrm{H}_{2}$ produced by reforming, $\mathrm{H}_{2}$ reacts with $\mathrm{CO}_{2}$ to yield $\mathrm{CO}$ and water. Thus one finds a higher $\mathrm{CO}$ yield compared to $\mathrm{H}_{2}$ and higher $\mathrm{CO}_{2}$ conversion compared to the methane conversion. A s shown in Fig. 9 the RWG S is not on thermodynamic equilibrium under our reaction conditions.

A t higher temperatures $(>1150 \mathrm{~K})$ a $\mathrm{H}_{2} / \mathrm{CO}$ ratio close to one can be obtained as then the water formed by the RWG S reaction can be consumed via the steam reforming (Fig. 10) to yield hydrogen and carbon monoxide. At temperatures over $1150 \mathrm{~K}$ the equilibrium for the steam reforming reaction shifts almost completely to the side of $\mathrm{H}_{2}$ and $\mathrm{CO}$. Thus, at these temperatures a higher driving force to produce only $\mathrm{H}_{2}$ and $\mathrm{CO}$ exists.

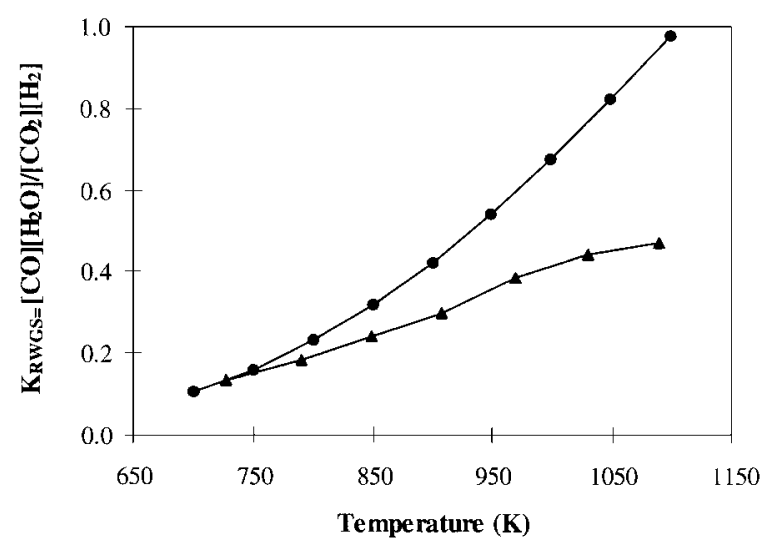

FIG. 9. Equilibrium values for the RWGS reaction $\left(\mathrm{H}_{2}+\mathrm{CO}_{2} \rightarrow\right.$ $\mathrm{CO}+\mathrm{H}_{2} \mathrm{O}$ ) obtained over $\mathrm{Pt} / \mathrm{ZrO}_{2}$ under $\mathrm{CO}_{2}$ reforming conditions ( $\boldsymbol{\Delta}$ ) and as calculated from thermodynamics (O).

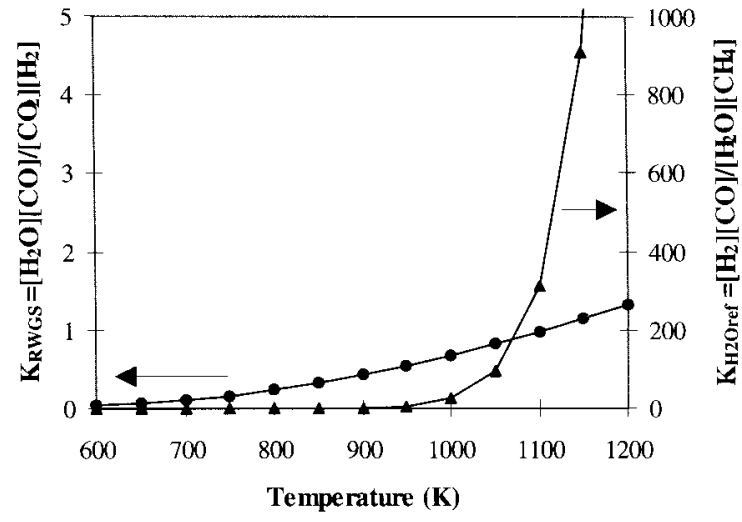

FIG. 10. K-values for the RWGS reaction $\left(\mathrm{H}_{2}+\mathrm{CO}_{2} \rightarrow \mathrm{CO}+\mathrm{H}_{2} \mathrm{O}\right)$ (-) and steam reforming $\left(\mathrm{H}_{2} \mathrm{O}+\mathrm{CH}_{4} \rightarrow 3 \mathrm{H}_{2}+\mathrm{CO}\right)$ ( $(\mathbf{\Delta})$ as calculated from thermodynamics.

\section{CONCLUSIONS}

In supported Pt catalysts not all the exposed Pt atoms contribute equally to the activity of the catalyst for $\mathrm{CO}_{2} / \mathrm{CH}_{4}$ reforming. Pt atoms on the support-metal perimeter determine the activity. This is explained in terms of the $\mathrm{CO}_{2}$ activation via carbonate species on the support that must be in the proximity of the Pt particles to react with the methane which is activated on the Pt. The perimeter concentration can be changed by either changing the metal loading or by changing the calcination temperature. The significance of the support is also manifested in the low activity of Pt black and $\mathrm{Pt} / \mathrm{SiO}_{2}$ which were incapable of forming carbonates on the support and showed a low activity for reforming. D uring high temperature reduction SM SI states evolve on $\mathrm{Pt} / \mathrm{Z} \mathrm{rO}_{2}$ catalysts. H owever, this state does not influence the activity of the catalyst, because adsorbed oxygen (from $\mathrm{CO}_{2}$ dissociation) destroys it under reaction conditions.

\section{ACK NOWLE D G MENTS}

This project was supported by the EU, Joule II programme, subprogramme: Energy from fossil sources: hydrocarbons, Contract J $\mathrm{O} U \mathrm{U}$ CT 92-0073. The X A FS measurements were carried out at the SR S, D aresbury Laboratory, U nited Kingdom. The authors are indebted to $M$. $\mathrm{E}$ nglisch and $\mathrm{A}$. J entys for valuable discussions on $\mathrm{XAFS}$ of $\mathrm{Pt} / \mathrm{ZrO} 2$.

\section{REFERENCES}

1. A schcroft, A. T., Cheetham, A. K., G reen, M. L. H ., and Vernon, P. D. F., N ature 225, 352 (1991).

2. R ichardson, J. T., and Paripatyadar, S. A ., A ppl. Catal. 61, 293 (1990).

3. Seshan, K., and Lercher, J. A ., in "Carbon D ioxide: E nvironmental Issues" (J. Paul and C. Pradier, Eds.), p. 16, The Royal Soc. Chem., Cambridge, 1994.

4. B hattacharya, A ., and Chang, V. W., Int. Conf. on Catalyst D eactivation, O ostende, O ct. 1994, Stud. Surf. Sci. Catal. 88, 207 (1994).

5. Kurz, G., and Teuner, S., E rdol. Kohle 43(5), 171 (1990). 
6. van den O osterkamp, P. F., Chen, Q ., O verwater, J. A . S., R oss, J.R . H ., and van K eulen, $A$. N. J., "M eeting of $L$ arge $C$ hemical Plants, $A$ ntwerp, Belgium, O ct. 1995."

7. Bodrov, I. M ., and A pel'baum, L. O., K inet. Katal. 8, 379 (1967).

8. U dengaard, N. R., B ak H ansen, J. H., H anson, D. C., and Stal, J. A., O il G as J. 90, 62 (1992).

9. Fischer, F., and Tropsch, H., B rennst. Chem. 39 (1928).

10. Solymosi, F., K utsan, G y., and E rdohelyi, A ., C atal. L ett. 11, 149 (1991).

11. Vernon, P. D. F., G reen, M . L . H ., Cheetham, A . K ., and A scroft, A . T., Catal. Today 13, 417 (1992).

12. Q in, D., and L apszewicz, J., Catal. Today 21, 551 (1994).

13. Nakamura, J., A ikawa, K., Sato, K., and U chijima, T., Catal. L ett. 25, 265 (1994).

14. R ostrup Nielsen, J. R ., J. Catal. 144, 38 (1993).

15. Perera, J. S., Sankar, J. W., and Thomas, J. M., Catal. L ett. 11, 219 (1991).

16. Tsipouriari, V. A ., E fstathiou, A . M ., Z hang, Z . L ., and Verykios, X .E ., Catal. Today 21, 579 (1994).

17. M ark, M . F., and M aier, W. F., A ngew. Chem. Int. E d. E ngl. 15-16, 33 (1994).

18. Sakai, Y., Saito, H., Sodesawa, T., and Nozaki, F., R eact. K inet. Catal. $L$ ett. 24, 253 (1984).

19. G adalla, A . M ., and Sommer, M . E ., Chem. Eng. Sci. 44, 2825 (1989).

20. Seshan, K ., ten B arge, H. W., H ally, W., van K eulen, A . N. J., and R oss, J. R. H., Stud. Surf. Sci. Catal. 81, 285 (1994).

21. Bitter, J. H., H ally, W., Seshan, K., van O mmen, J. G., and Lercher, J. A ., Catal. Today 29, 349 (1996).
22. Lercher, J. A., Bitter, J. H., H ally, W., Niessen, W., and Seshan, K., Stud. Surf. Sci. Catal. 101, 463 (1996).

23. Seshan, K., M ercera, P. D. L., X ue, E., and R oss, J. R. H., German Patent P4313673, 1994. [I nternational patent W O 94/224042, 1994]

24. K ip, B. J., D uivenvoorden, F. B. M., Koningsberger, D. C., and Prins, R., J. Catal. 105, 26 (1987).

25. Vaarkamp, M., G rondelle, J. V., M iller, J. T., Sajkowski, D. J., M odica, F. S., L ane, G. S., G ates, B. C., and Koningsberger, D. C., C atal. L ett. 6, 369 (1990).

26. Paal, Z., Z han, Z., Fulop, E ., and Tesche, B., J. Catal. 156, 19 (1995).

27. Scholten, J. J. F., Pijpers, A . P., and H ustings, A . M . L ., Catal. R ev.-Sci. Eng. 27 (1985).

28. Tauster, S. J., Fung, S. C., and G arten, R. L., J. A m. Chem. Soc. 100, 170 (1978).

29. Tauster, S. J., A cc. Chem. Res. 20, 389 (1987).

30. L evin, M. E ., Salmeron, M., B ell, A . T., and Somorjai, G. A ., J. Chem. Soc. Faraday Trans. 1 83, 2061 (1987).

31. L evin, M. E ., Salmeron, M ., B ell, A . T., and Somorjai, G. A ., J. Catal. 106, 401 (1987).

32. B offa, A. B., L in, C., B ell, A . T., and Somorjai, G. A ., Catal. L ett. 27, 243 (1994).

33. Koerts, T., Welters, W. J. J., and van Santen, R. A., J. Catal. 134, 1 (1992).

34. G renoble, D. C., E dstadt, M . M ., and O Ilis, D. F., J. Catal. 67, 90 (1981).

35. Turlier, P., and M artin, G. A ., R eact. K inet. Catal. L ett. 21, 287 (1982).

36. D all'A gnol, C., G ervasini, A ., M orazzoni, F., Pinna, F., Stukul, G., and Zanderighi, L., J. Catal. 96, 106 (1985). 